\title{
From Corn to Rice: Cultural Conception of Food among the Madurese Community Indonesia
}

\author{
Sebastianus Nawiyanto* \\ Faculty of Cultural Sciences, University of Jember, Indonesia
}

Submission: June 14, 2019; Published: June 27, 2019

*Corresponding author: Sebastianus Nawiyanto, Faculty of Cultural Sciences, University of Jember, Jawa Timur, Indonesia

\begin{abstract}
Food is closely linked to culture. The choice of food is not solely based on nutritional considerations, but also involves far more complex considerations such as group identity and symbolical function. This paper discusses the meaning of food for Madurese ethnic group, Indonesia. More specifically it will be studied the adoption of corn as a staple food and shifting staple food from corn to rice in the Madurese ethnic group. It is argued that for Madurese community the shifting of staple food is a reasonable historical process and takes place for various reasons.
\end{abstract}

Keywords: Corn; Rice; Cultural conception; Food shift; Madurese Community

\section{Mini Review}

The Madurese people have been familiar with a variety of foods. There are three foods that are most often mentioned in colonial reports, namely corn, rice, and cassava [1]. Among the three foodstuffs, corn once occupied an important position before later being replaced by rice. Corn has been seen as an integral part of the Maduerese ethnic identity. The significance of corn is evident from the stereotype that developed and is often attached to the Madurese as corn eaters [2]. The important position of corn for the Madurese ethnic group is reflected in various Madurese folklore. In a collection of folklore from Madura, for example, corn is part of it [3]. In other traditional Madurese story, Lesap, corn is also mentioned. When facing Prince Tjakraningrat and giving an explanation of the king's questions, Patih Ardja Mantjanegara, among others, replied, "The people prospered, the conditions of the countryside were safe, the corn trees had begun to flower ...". In another part, when asked by the king about his work, Lesap replied, "The servant does not have a job, except planting corn [4]...." In both Madurese literature, rice does not appear at all.

In Madurese society, corn has various functions. In addition to consumption item, corn is also used as a means to strengthen kinship and social relations. Even until 1980s when people die, mourners, especially mothers, always bring corn to be handed over to the bereaved family [5]. Corn also has an important position as a means of ritual activities. Corn is one of the ingredients in the offering when establishing a house [6]. Despite its importance, corn which was once the identity of Madura is not native to the island of Madura. Corn is believed to originate from the American continent and is generally known as a staple food of Indian tribes [7]. From the Americas, corn spread throughout the world during the post-Columbian food exchange process along with the colonization of Westerners. In new places, a number of new plants were even expanding widely. Even on Madura island, corn was the most important food crop [8]. It is estimated that corn has been widespread in Madura since 1550 and at the beginning of the 19th century Thomas Stamford Raffles intended to make corn as a measure to set taxes on dry land [9].

There are several basic reasons that made corn a popular crop among the Madurese ethnic group. First, corn offers higher productivity per unit of land and labor. Compared to rice, corn provides a higher yield ratio, guaranteeing greater crop success, with relatively low labor requirements. Second, corn has several advantages. The needs of the growing environment of this plant are more flexible, including less fertile areas. To grow corn requires irrigation in a much less volume than rice. In terms of cultivation techniques, corn planting can be done intercropping with other plants, so as to reduce the risks and losses due to crop failure [10]. Similar reasons also underlie why corn is popularly accepted in African regions [11]. Because the expansion of agricultural land was mostly in the dry land areas and investment in irrigation networks requiring large costs, one of the most appropriate adaptation patterns was through the choice of plants suitable for limited irrigation environments. In such an ecological context, the choices of commodities available were corn and cassava. The advantages of corn compared to cassava 
were among others in terms of prices that were much higher and easier to store for a long period of time. Unlike corn, cassava must be consumed immediately a few days after harvesting. For long-term consumption, the cassava preservation process was more complicated and without adequate handling the quality decreases quickly. Another reason was more important, corn plants provide feed for livestock, especially cattle, domestic animals that are very important among Madurese. The importance of cattle for them leads to a stereotype that the Madurese love cows more than their wives [12].

Madurese preferences for corn began to shift in the New Order era. With the food crisis backround in the 1960s, the New Order government targeted increasing rice production through a green revolution policy. Besides providing various components of production, including seed technology, fertilizers and pesticides, irrigation sector development was one of the pillars. In Madura, the expansion of rice plants or what Kuntowijoyo termed a "process of ricefication " was inseparable from the introduction of water pumps for agriculture and the discovery of various short-lived rice varieties [13]. The reduced area of corn cultivation reflected the shift in staple food preference among the Madurese. The position of corn as staple food began to be replaced by rice. This shift can be recognized by comparing the two phenomena that contradict the tendency. On the one hand, the Madurese population continues to grow and food needs are increasing. On the other hand, corn cultivation has actually decreased in area and corn production has also declined. It can be ascertained that the food needs of the Madurese are fulfilled by the consumption of non-corn food, and in this case rice. A historian who is an expert on Madura describes, "food stalls in Madura now also no longer provide corn food but rice [14]..."

In addition to ecological changes, the shift in consumption of staple foods from corn to rice among Madurese is related to a number of factors. Economically the government policy of providing subsidies for production facilities and fixing the price of rice on the market, which is also supported by the rice import policy, succeeded in suppressing seasonal fluctuations in rice prices. Rice becomes relatively stable in price and, no less important, can be affordable by people's purchasing power. The combination of various policies is an important incentive that drives the transition of eating patterns with rice as the main component. Another advantage of rice is the ease in the preparation process compared to corn which requires more time and is complex. The shift to rice is also related to the flow of Madurese migrants to Java who play an important role in introducing rice culture to its original place when going home [15].

From a sociological perspective, rice consumption is considered to have a higher prestige than corn. Rice has a special position. In the 1990s for the purposes of ceremonies and weddings, the standard is rice [16]. Symbolically corn consumption as well as cassava as a basic component of the diet is often considered in Indonesian society in the past as a sign of poverty [17]. The same thing was expressed in a statement that appeared around 70 years ago that the replacement of rice with other foods was seen as a setback [18]. In several other places in the world including France and Italy, only the poor people used to adopt corn as a staple food [19]. Changes in the pattern of consumption of staple food from corn to rice are regarded as a sign of success in vertical social mobility from the lower strata to the higher social strata. This is parallel with Lury's view that the practice of consumption is also closely linked with cultural and symbolic nuances. Consumption practices are part of the struggle of individuals to reach social class positions, not merely a means of meeting biological or economic needs. In other words, through food people also intend to define their social status in society [20]. The Madurese also don't seem to be different. For them a shift from corn to rice is part of an effort to prove success in improving class position.

\section{References}

1. Kartodirdjo S (1978) Memori Serah Jabatan 1921-1930, Jawa Timur dan Tanah Kerajaan. Arsip Nasional Republik Indonesia, Jakarta, Indonesia.

2. De Jonge $H$ (1995) Stereotypes of the Madurese. In Kees van Dijk, Huub de Jonge dan Elly Touwen-Bouwsma (Eds.), Across Madura Strait: The Dynamics of an Insular Society. KITLV Press, Leiden, The Netherlands, pp. 7-24.

3. Zawawi Imron D (1993) Cerita Rakyat dari Madura. Grasindo, Jakarta, Indonesia.

4. Hatib W (1960) Adat Istiadat dan Tjerita Rakjat. Djawatan Kebudajaan Dep. PP dan K, Jakarta, Indonesia.

5. Kuntowijoyo (1991) Bergesernya Pola Pangan Pokok di Madura. Pangan, 2(9): 20-25.

6. Moelyono dan Gatut Murniatmo (1985) Mengenal Sekelumit Kebudayaan Orang Madura di Sumenenp. Balai Kajian Sejarah dan Nilai Tradisional, Yogyakarta, Indonesia.

7. Vander Veer K (1948) Mais. In: Van Hall CJJ, Vande Koppel C (Eds.), De Landbouw in de Indische Archipel. Van Hoeve, The Hague, The Netherlands, 2: 111-156.

8. Melhus IE, Jackson RI (1952) Corn Growing in Indonesia and Some Suggestions for Increasing Production. Landbouw, 24: 361-399.

9. Boomgaard (1999) Corn dan Tobacco in Upland Indonesi. In Tania Murray Li (Eds.), Transforming the Indonesian Uplands: Marginality, Power and Production. Institute of Southeast Asian Studies, Singapore, p. 45-78.

10. Boomgaard (1999) p. 63-64.

11. Tannahill R (1973) Food in History. Stein and Day, New York, USA.

12. De Jonge (1995) p. 17.

13. Kuntowijoyo (1991) p. 21

14. Kuntowijoyo (1991) p. 22

15. Kuntowijoyo (1991) p. 21.

16. Kuntowijoyo (1991) p. 20-21. 
17. Booth A (1998) The Economic Development of Southeast Asia: 18701985. Australian Economic History Review 31: 20-52.

18. Sjafei M (1949) Soal Beras di Tanah Indonesia. Pertanian Ra'iat 4(5): 3-4.
19. Tannahill (1973) pp. 248.

20. Kittler PG and Sucher PH (2008) Food and Culture. Thomson Wadsworth, Belmont, USA.

\section{Your next submission with Juniper Publishers} will reach you the below assets

- Quality Editorial service

- Swift Peer Review

- Reprints availability

- E-prints Service

- Manuscript Podcast for convenient understanding

- Global attainment for your research

- Manuscript accessibility in different formats

( Pdf, E-pub, Full Text, Audio)

- Unceasing customer service

Track the below URL for one-step submission https://juniperpublishers.com/online-submission.php 